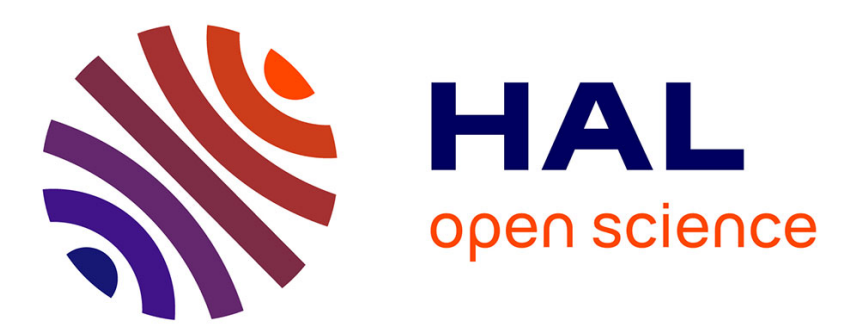

\title{
Theoretical aspects of an equilibrium study in the non-dissociating molecular solvent acetic acid.
}

Mustayeen A. Khan, Meullemeestre J., Vierling F., M.J. Schwing

\section{To cite this version:}

Mustayeen A. Khan, Meullemeestre J., Vierling F., M.J. Schwing. Theoretical aspects of an equilibrium study in the non-dissociating molecular solvent acetic acid.. Polyhedron, 1990, 9 (21), pp.26132617. hal-03165654

\section{HAL Id: hal-03165654 \\ https://univ-angers.hal.science/hal-03165654}

Submitted on 11 Mar 2021

HAL is a multi-disciplinary open access archive for the deposit and dissemination of scientific research documents, whether they are published or not. The documents may come from teaching and research institutions in France or abroad, or from public or private research centers.
L'archive ouverte pluridisciplinaire HAL, est destinée au dépôt et à la diffusion de documents scientifiques de niveau recherche, publiés ou non, émanant des établissements d'enseignement et de recherche français ou étrangers, des laboratoires publics ou privés. 


\title{
THEORETICAL ASPECTS OF AN EQUILIBRIUM STUDY IN THE NON-DISSOCIATING MOLECULAR SOLVENT ACETIC ACID
}

\author{
M. A. KHAN, J. MEULLEMEESTRE, M. J. SCHWING and F. VIERLING* \\ Laboratoire de Chimie-Physique, URA n 405. EHICS, Université Louis Pasteur, \\ 1 rue Blaise Pascal, F-67008 Strasbourg Cedex, France
}

(Received 23 April 1990; accepted 22 June 1990)

\begin{abstract}
The bromide complexes of copper(II) were studied spectrophotometrically in acetic acid. This non-dissociating solvent presents secondary equilibria such as perchlorate $\rightleftarrows$ acetate and in the case of copper acetate in acetic acid, monomer $\rightleftarrows$ dimer. A matrix rank treatment of the optical densities identified four mononuclear bromo complexes which are formulated as $\mathrm{Cu}(\mathrm{OAc}) \mathrm{Br}, \mathrm{CuBr}_{2}, \mathrm{LiCuBr}_{3}$ and $\mathrm{Li}_{2} \mathrm{CuBr}_{4}$. The overall stability constants of these species are $\log \beta_{1}=3.2, \log \beta_{2}=6.5, \log \beta_{3}=7.7$ and $\log \beta_{4}=7.7$. The electronic spectra of the individual species, in this solvent, are reported for the first time. The $d-d$ transition band of the tetrabromocuprate is calculated to be at $1120 \mathrm{~nm}$ and confirms the structure of a flattened tetrahedron.
\end{abstract}

According to the classification of the solvents based on the dielectric constant, $\varepsilon_{\mathrm{r}}$, solvents with values of $\varepsilon_{\mathrm{r}}<15$ are classified as non-dissociating molecular solvents. Acetic acid, $\varepsilon_{\mathrm{r}}=6.2$, falls under this category and is therefore non-ionic in character and species present in this solvent exist as ion-pairs or ionic aggregates. ${ }^{1}$ However, an equilibrium study in this solvent poses a host of theoretical problems which we shall indicate with a concrete example. Having already reported studies of halogenocuprates in different protic and aprotic solvents ${ }^{2-5}$ we shall illustrate these problems with the help of results of copper(II) bromides in acetic acid, at $25^{\circ} \mathrm{C}$ and at a constant molecular environment maintained at $1 \mathrm{~mol} \mathrm{dm}^{-3}$.

\section{PROBLEM OF THE NATURE OF SALT}

In all our previous studies the metal coordinator was introduced into the solution by using a solution of copper(II) perchlorate. However, at low concentration of copper perchlorate in acetic acid, the formation of copper acetate is remarked. Copper perchlorate has a characteristic absorption band at $790 \mathrm{~nm}$, whereas copper acetate absorbs at $680 \mathrm{~nm}$.

* Author to whom correspondence should be addressed.
Eswein et al. ${ }^{6}$ and Sawada et al. ${ }^{7}$ have reported the absorption of copper acetate at 670 and $685 \mathrm{~nm}$, respectively. In acetic solutions and at higher concentrations of copper perchlorate, its characteristic maximum is clearly observed at $790 \mathrm{~nm}$. With dilution of the solution this maximum undergoes a hypsochromic effect and shifts to $680 \mathrm{~nm}$, thus indicating the presence of copper acetate. Figure 1(a) and (b) shows the effect of dilution of copper perchlorate solution in acetic acid, respectively, in the presence, as well as in the absence, of lithium perchlorate $\left(1 \mathrm{~mol} \mathrm{dm}^{-3}\right)$. There is therefore an equilibrium between perchlorate and acetate:

$$
\mathrm{Cu}\left(\mathrm{ClO}_{4}\right)_{2} \rightleftarrows \mathrm{Cu}\left(\mathrm{ClO}_{4}\right)(\mathrm{OAc}) \rightleftarrows \mathrm{Cu}(\mathrm{OAc})_{2} .
$$

Copper perchlorate absorbs at $790 \mathrm{~nm}$, copper acetate at $680 \mathrm{~nm}$ and, in between, a mixed salt of the two has an absorption maximum at about $720 \mathrm{~nm} .{ }^{10}$

Under these conditions a study of the halogeno complexes of copper in acetic acid with copper perchlorate is nearly impossible because the form of the non-complexed copper in the solution is unknown: whether it is in the form of perchlorate or acetate, or in the form of the mixed salt especially when the concentration of copper is low. Furthermore, Fig. 1(a) indicates that even the addition of lithium perchlorate as indifferent electrolyte fails to stabilize copper in the form of copper perchlorate. 

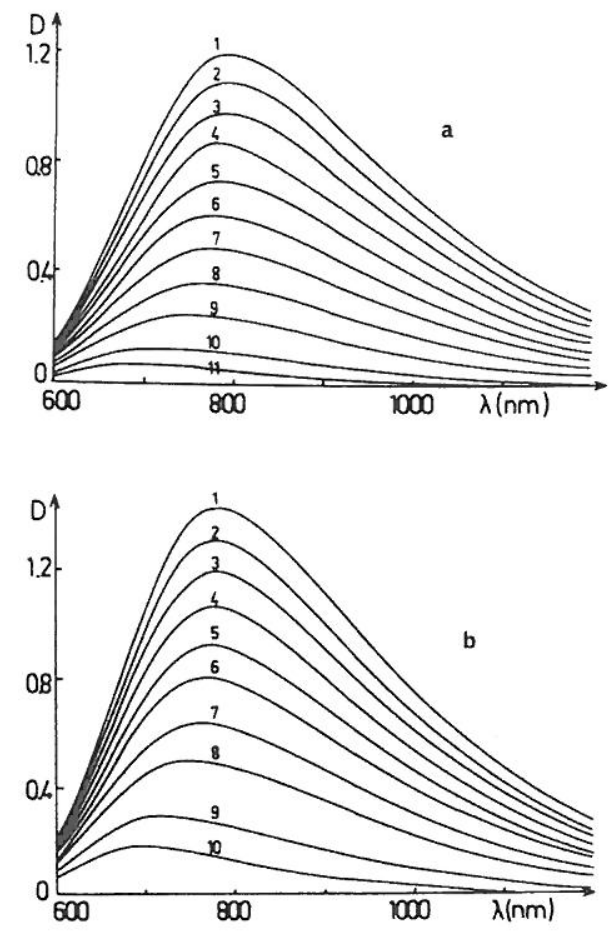

Fig. 1. Dilution of copper(II) perchlorate solution in acetic acid: (a) in the absence of $\mathrm{LiClO}_{4}$; (b) in the presence of $\mathrm{LiClO}_{4}$.

Consequently in a study of the halogeno complexes of copper(II) in acetic acid, copper must be added in the form of copper acetate.

\section{MONOMER-DIMER EQUILIBRIUM}

The use of copper acetate in acetic acid engenders a different type of problem, that of the existence of a monomer-dimer equilibrium: $2 \mathrm{Cu}(\mathrm{OAc})_{2} \rightleftarrows$ $\mathrm{Cu}_{2}(\mathrm{OAc})_{4}$. Yamada et $a l .{ }^{8}$ and Martin and Whitley ${ }^{9}$ have shown that the absorption band of copper acetate in acetic acid at $365 \mathrm{~nm}$ is due to metal-metal bonding in copper acetate which exists as a dimer in solution. Sawada et al. ${ }^{10}$ have reported this absorption maximum at $370 \mathrm{~nm}$. This band is not observed in our work because of low copper concentration, but it is observed at 372 $\mathrm{nm}$ in concentrated solutions of copper acetate $\left[\mathrm{Cu}^{\mathrm{II}}\right]>4 \times 10^{-3} \mathrm{~mol} \mathrm{dm}^{-3}$.

The equilibrium constant of the monomer-dimer equilibrium has been determined by Kochi and Bubramanian" and is equal to $5 \times 10^{-4}$. These authors have also reported the feeble absorption intensity of the dimer band $\left(\varepsilon<60 \mathrm{dm}^{3} \mathrm{~mol}^{-1}\right.$ $\mathrm{cm}^{-1}$ ). The existence of the monomer and dimer species has been confirmed with the help of magnetic susceptibility measurements by Sawada et al. ${ }^{7}$ who have shown that the copper acetate in acetic acid has a dimeric structure, whereas the chloro complexes of copper are monomeric in nature.

Taking into consideration all these factors: (1) the low value of the equilibrium constant of monomer $\rightleftarrows$ dimer, (2) the very low absorption intensity of the dimer, (3) the disappearance of copper acetate in favour of the formation of bromo complexes. in our study, as well as the low concentrations of copper solutions, it can be assumed that copper acetate is in the monomeric form as far as this work is concerned. This hypothesis is further sustained by the fact that addition of small quantities of perchloric acid, which is the case in our study, favours the monomeric species. ${ }^{11}$

\section{EQUILIBRIUM OF BROMO COMPLEXES OF COPPER(II) IN ACETIC ACID}

In dissociating protic or aprotic solvents, the complexes involved in the equilibrium reaction are either charged or neutral species, generally cations more solvated than anions and sometimes completely unsolvated anions such as $\mathrm{CuX}_{4}{ }^{2-}$, the electronic spectrum of which was demonstrated as solvent independent. ${ }^{3}$

On the contrary, in the non-dissociating aprotic solvents such as $\mathrm{THF}^{4}$ or protic solvents such as acetic acid, the species are present as ion-pairs or ion-aggregates and the successive equilibria in solution can be written as:

$$
\begin{aligned}
\mathrm{Cu}(\mathrm{OAc})_{2}+\mathrm{LiBr} & \rightleftarrows \mathrm{Cu}(\mathrm{OAc}) \mathrm{Br}, \mathrm{LiOAc} \\
\mathrm{Cu}(\mathrm{OAc})_{2}+2 \mathrm{LiBr} & \rightleftarrows \mathrm{CuBr}_{2}, 2 \mathrm{LiOAc} \\
\mathrm{Cu}(\mathrm{OAc})_{2}+3 \mathrm{LiBr} & \rightleftarrows \mathrm{LiCuBr}_{3}, 2 \mathrm{LiOAc} \\
\mathrm{Cu}(\mathrm{OAc})_{2}+4 \mathrm{LiBr} & \rightleftarrows \mathrm{Li}_{2} \mathrm{CuBr}_{4}, 2 \mathrm{LiOAc} .
\end{aligned}
$$

However, the so-called non-dissociating solvents are only so by definition in the case of relative permittivity values, $\varepsilon_{\mathrm{r}}$, lower than 15 . For acetic acid which has an $\varepsilon_{\mathrm{r}}$ of 6.2 there is nevertheless the feeble ionization present. The presence of such voluminous ion-aggregates as $\mathrm{LiCuBr}_{3}, 2 \mathrm{LiOAc}$ or $\mathrm{Li}_{2} \mathrm{CuBr}_{4}, 2 \mathrm{LiOAc}$ is quite improbable. Consequently, the sequence of the equilibria should be written in the following way:

$$
\begin{aligned}
\mathrm{Cu}(\mathrm{OAc})_{2}+\mathrm{LiBr} & \rightleftarrows \mathrm{Cu}(\mathrm{OAc}) \mathrm{Br}+\mathrm{LiOAc} \\
\mathrm{Cu}(\mathrm{OAc})_{2}+2 \mathrm{LiBr} & \rightleftarrows \mathrm{CuBr}_{2}+2 \mathrm{LiOAc} \\
\mathrm{Cu}(\mathrm{OAc})_{2}+3 \mathrm{LiBr} & \rightleftarrows \mathrm{LiCuBr}_{3}+2 \mathrm{LiOAc} \\
\mathrm{Cu}(\mathrm{OAc})_{2}+4 \mathrm{LiBr} & \rightleftarrows \mathrm{Li}_{2} \mathrm{CuBr}_{4}+2 \mathrm{LiOAc} .
\end{aligned}
$$

As a matter of fact, the equilibrium constants corresponding to formulation (b) are different from those used in ionic media or aprotic dissociating 
solvents. This difference is essentially due to the presence of the LiOAc concentration in the numerator. Amuli et al. ${ }^{4}$ maintained the molecular environment constant in THF by the addition of $\mathrm{LiClO}_{4}$, which enabled its exact analytical concentration to be known. By analogy, LiOAc should be used in these solutions. Unfortunately, copper(II) possesses good coordination ability with lithium acetate, unlike with perchlorate, and would consequently lead to another set of equilibria which overlap with the copper(II) bromides under study. Without addition of LiOAc, calculation of its concentration, taking into account equilibria (b), is quite impossible.

Therefore, the determination of the equilibrium constants of the copper(II) bromo complexes is performed using formulation (a) generalized by:

$$
\mathrm{Cu}(\mathrm{OAc})_{2}+\mathrm{jLiBr} \rightleftarrows \text { complex j, }
$$

with an equilibrium constant $\beta_{\mathrm{j}}=[$ complex $\mathrm{j}] /$ $\left[\mathrm{Cu}(\mathrm{OAc})_{2}\right][\mathrm{LiBr}]^{\mathrm{j}}$.

\section{COPPER(II) BROMIDES IN ACETIC ACID}

Keeping in view all the above aspects we report below the results of copper(II) bromo complexes in acetic acid. Eswein et al. ${ }^{6}$ have already reported the existence of the tri- and tetrabromocuprates in acetic acid absorbing at 625 and $510 \mathrm{~nm}$, respectively. Yatsimirskii and Mal'Kova have calculated the stability constants of the mono- and dibromo complexes $\left(\log \beta_{1}=2.60\right.$ and $\left.\log \beta_{2}=6.42\right)$ in acetic acid. ${ }^{12}$ In another publication, these authors postulated the presence of tetra- and hexabromo complexes in concentrated solutions. ${ }^{13}$

Figure 2 shows the experimental spectra of the copper(II) bromides in the UV-vis and the near-IR regions. As soon as the ligand is added to the copper solutions, the copper absorption band at $260 \mathrm{~nm}$ diminishes with the appearance of several maxima:

an absorption band at $285 \mathrm{~nm}$ which increases in intensity with concentration and at the same time undergoes a hypsochromic shift until $267 \mathrm{~nm}$ for $C=1.0 \mathrm{~mol} \mathrm{dm}^{-3}$;

another maximum at $350 \mathrm{~nm}$, increasing with concentration until $C=0.01 \mathrm{~mol} \mathrm{dm}^{-3}$, with a bathochromic shift until $370 \mathrm{~nm}$. For $\geqslant 0.03 \mathrm{~mol}$ $\mathrm{dm}^{-3}$ this maximum diminishes in intensity and shifts back to $350 \mathrm{~nm}$;

the appearance in the visible range of two absorption bands at 435 and $640 \mathrm{~nm}$ following the same evolution pattern as the $350 \mathrm{~nm}$ band. In addition to these bands in the visible spectrum, another band appears at $520 \mathrm{~nm}$ for ligand concentrations superior to $0.1 \mathrm{~mol} \mathrm{dm}^{-3}$;

in the near-IR, the maximum at $860 \mathrm{~nm}$ increases in intensity until $C=0.05 \mathrm{~mol} \mathrm{dm} \mathrm{dm}^{-3}$ and then diminishes in favour of a large band centred at $1170 \mathrm{~nm}$.

A matrix rank treatment of optical densities was executed to determine the minimum number of species present in the solution, ${ }^{14}$ which indicated the presence of at least three complexes. The theoretical expressions and the mathematical treatment have

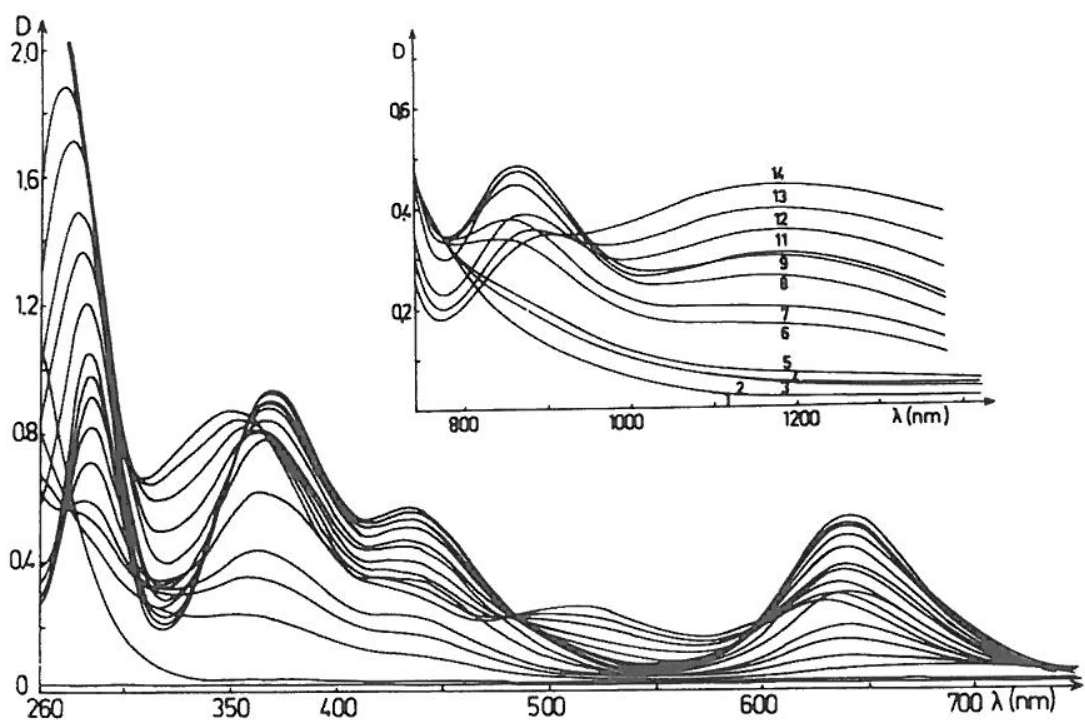

Fig. 2. Copper(II) bromide absorption spectra in acetic acid. (a) UV-vis, $B=5 \times 10^{-4} \mathrm{M}, l=0.5$ $\mathrm{cm}$, spectra $/ 10^{3} \times C(\mathrm{M}): 1 / 0.5 ; 2 / 0.8 ; 3 / 1 ; 4 / 1.5 ; 5 / 2 ; 6 / 3 ; 7 / 5 ; 8 / 10 ; 9 / 30 ; 10 / 60 ; 11 / 100 ; 12 / 200$; $13 / 400 ; 14 / 600 ; 15 / 800 ; 16 / 1000$. (b) Proche IR, $B=1.5 \times 10^{-3} \mathrm{M}, l=2 \mathrm{~cm}$, spectra $/ 10^{3} \times C(\mathrm{M})$ : $10 ; 20.5 ; 3: 1 ; 4 / 1.5 ; 5 ; 2 ; 6 / 4 ; 75 ; 8 ; 7 ; 9: 10 ; 1040 ; 11 / 100 ; 12 / 400 ; 13 / 700 ; 14 / 1000$. 
Table 1. Results of the numerical analysis of the theoretical models $[1,2,3]$ and $[1,2,3,4]$

\begin{tabular}{ccc}
\hline $\begin{array}{c}\text { Overall } \\
\text { stability } \\
\text { constant }\end{array}$ & Model $[1,2,3]$ & Model $[1,2,3,4]$ \\
\hline$\beta_{1}$ & $(8.9 \pm 6.0) \times 10^{2}$ & $(1.7 \pm 0.7) \times 10^{3}$ \\
$\beta_{2}$ & $(2.0 \pm 1.0) \times 10^{6}$ & $(3.0 \pm 1.1) \times 10^{6}$ \\
$\beta_{3}$ & $(8.9 \pm 6.0) \times 10^{6}$ & $(5.5 \pm 3.0) \times 10^{7}$ \\
$\beta_{4}$ & - & $(5.5 \pm 3.5) \times 10^{7}$ \\
$\sigma_{\mathrm{t}}$ & 0.069 & 0.052 \\
\hline
\end{tabular}

been explained in one of our earlier publications. ${ }^{3}$ The computation was performed on the $[1,2,3]$ and $[1,2,3,4]$ theoretical models, i.e. the mono-, di- and tribromo complexes and the mono-, di-, tri- and tetrabromo complexes, respectively. The results are summarized in Table 1.

The quadratic mean $\left\langle\sigma_{\mathrm{t}}\right\rangle$ has a significantly lower value for the model with four complexes. Consequently the presence of four mononuclear bromo complexes is concluded and, in acetic acid, they are formulated as $\mathrm{Cu}(\mathrm{OAc}) \mathrm{Br}, \mathrm{CuBr}_{2}, \mathrm{LiCuBr}_{3}$ and $\mathrm{Li}_{2} \mathrm{CuBr}_{4}$. The values of the stability constants are used to determine the specific molar extinction coefficients, $\varepsilon_{\mathrm{j}}$, to calculate the electronic spectra of the individual species represented in Fig. 3. The characteristic charge-transfer bands, as well as the $d-d$ transitions for the individual complexes, are reported in the Table 2 .

The formation curves of the four complexes are represented in Fig. 4, and it is seen that $\mathrm{CuBr}_{2}$
Table 2. The characteristic charge-transfer and the $d-d$ transition bands of the copper(II) bromo complexes in acetic acid

\begin{tabular}{lccl}
\hline $\mathrm{CuOAcBr}$ & $\mathrm{CuBr}_{2}$ & $\mathrm{LiCuBr}_{3}$ & \multicolumn{1}{c}{$\mathrm{LiCuBr}_{4}$} \\
\hline $314(3080)$ & $284(3650)$ & $275(7160)$ & $260(11,000)$ \\
& $370(4000)$ & $370(3080)$ & $336(4600)$ \\
& $440(2440)$ & $440(1840)$ & $410 \mathrm{sh}$ \\
& & & $520(1570)$ \\
& $640(2200)$ & $640(1800)$ & $590 \mathrm{sh}$ \\
$752(126)$ & $860(157)$ & $880(152)$ & $780 \mathrm{sh}$ \\
$960 \mathrm{sh}$ & $1130(86)$ & $1220(112)$ & $1120(166)$
\end{tabular}

covers a large range of ligand concentration. Even with a maximum experimental concentration of 1.0 mol dm ${ }^{-3}$, where $49 \%$ of the third and $49 \%$ of the fourth complex are formed, small quantities of the dibromo complex are still present.

Our earlier works concerning the structure in solution of the tetrachlorocuprates have demonstrated both the square-planar and flattened tetrahedron configurations depending upon the solvents. As regards the tetrabromo complex, all studies converge to attribute the flattened tetrahedron structure for it. In the solid state, this configuration has a very specific $d-d$ transition band at $1111 \mathrm{~nm}$ and above. Our calculations show its maximum at $1120 \mathrm{~nm}$ and therefore, by comparison with solids, the structure of the tetrabromocuprate, in acetic acid solution, is that of a flattened tetrahedron.

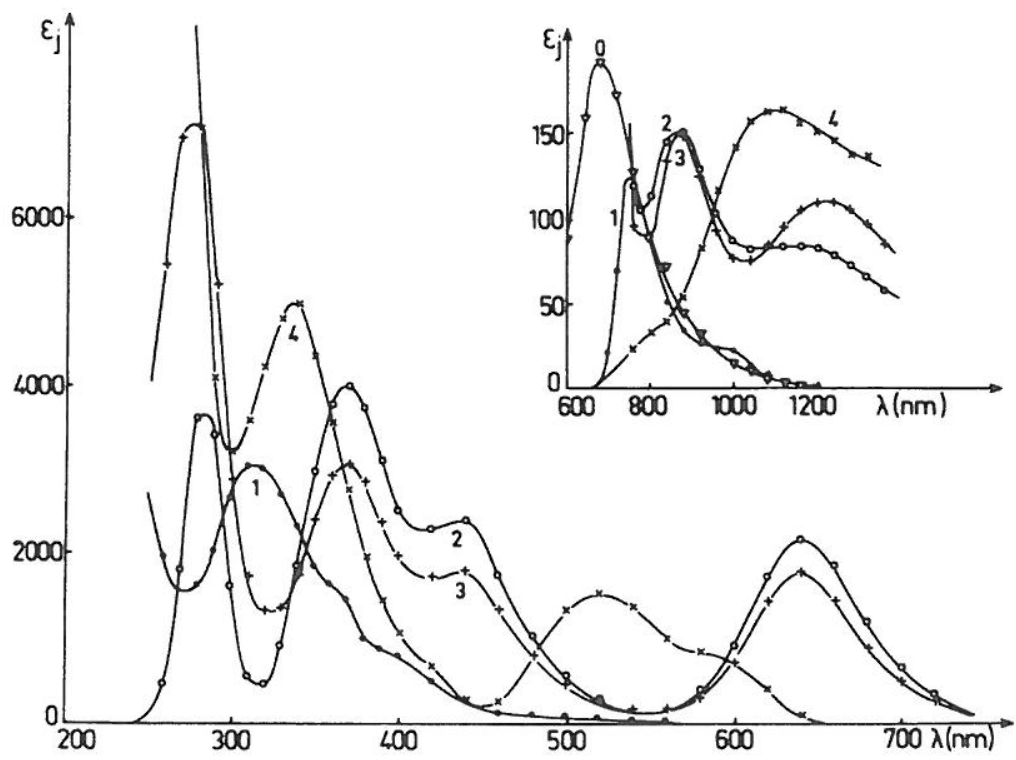

Fig. 3. Calculated electronic spectra of the copper(II) bromo complexes in acetic acid : (0) $\mathrm{Cu}(\mathrm{OAc})_{2}$, (1) $\mathrm{Cu}(\mathrm{OAc}) \mathrm{Br}$, (2) $\mathrm{CuBr}_{2}$, (3) $\mathrm{LiCuBr}_{3}$, (4) $\mathrm{Li}_{2} \mathrm{CuBr}_{4}$. 


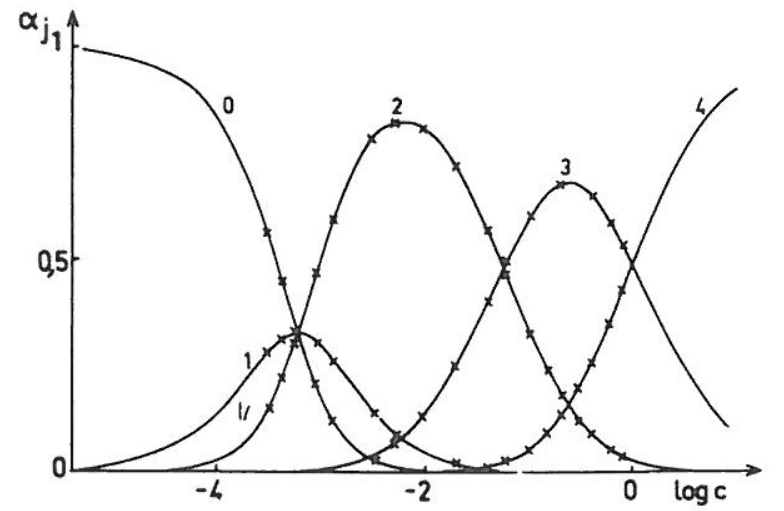

Fig. 4. Degree of formation of the copper(II) bromo complexes in acetic acid, ( $c$ is the effective concentration of $\mathrm{LiBr}) ;(\times)$ experimental points.

\section{EXPERIMENTAL}

Anhydrous acetic acid, pro-analysis (Merck), was used after the addition of a calculated amount of acetic anhydride, p.a. Merck, along with three drops of $0.001 \mathrm{M}$ perchloric acid, $70 \%$ p.a. Merck, and then allowing the solution to stand overnight. ${ }^{1}$ Copper solutions were prepared from stock solutions of copper(II) acetate, p.a. Merck, and $\mathrm{Cu}\left(\mathrm{ClO}_{4}\right)_{2} \cdot 6 \mathrm{H}_{2} \mathrm{O}$, p.a. Merck. Lithium bromide, p.a. Merck, and lithium perchlorate, p.a. Fluka, were used without any purification.

The final analytical concentration of copper was $5 \times 10^{-4} \mathrm{~mol} \mathrm{dm}^{-3}$ for measurements in the UVvis and $3.75 \times 10^{-3} \mathrm{~mol} \mathrm{dm}^{-3}$ in the IR region. In these spectral ranges ligand concentrations were

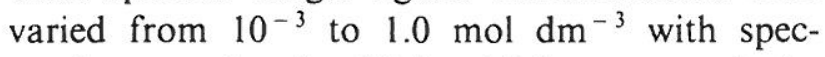
trophotometric cells of 0.5 and $2.0 \mathrm{~cm}$, respectively.

Acetic acid was used as the spectrophotometric reference solution. The final solutions of copper and bromide were prepared just before measurements to avoid any possibility of errors due to instability. The absorption of the solutions was measured with the help of CARY 17D with digital interfacing and a Periferic Zip 30 rapid printer. The numerical analysis was performed on an IBM 3081 D computer.

\section{REFERENCES}

1. A. I. Popov, The Chemistry of Non-aqueous Solvents (Edited by J. J. Lagowski), Part III. Academic Press, New York (1970).

2. M. A. Khan and M. J. Schwing, Inorg. Chem. 1976, 15, 2202; Bull. Soc. Chim. Fr. 1977, 3-4, 399.

3. M. Elleb, J. Meullemeestre, M. J. Schwing and F. Vierling, Inorg. Chem. 1980, 19, 2699; 1982, 21, 1477.

4. C. Amuli, J. Meullemeestre, M. J. Schwing and F. Vierling, Inorg. Chem. 1983, 22, 3567; 1986, 25, 856; Nouv. J. Chim. 1987, 11, 27.

5. M. A. Khan, J. Meullemeestre, M. J. Schwing and F. Vierling, Polyhedron 1983, 2, 459; Inorg. Chem. 1989, 28, 3306.

6. R. P. Eswein, E. S. Howald, R. A. Howald and D. P. Keeton, J. Inorg. Nucl. Chem. 1967, 29, 437.

7. K. Sawada, H. Ohtaki and M. Tanaka, J. Inorg. Nucl. Chem. 1972, 34, 3455.

8. S. Yamada, H. Nakamura and R. Tuchida, Bull. Chem. Soc. Jpn 1957, 30, 953.

9. R. L. Martin and A. Whitley, J. Chem. Soc. 1958, 1394.

10. K. Sawada, H. Ohtaki and M. Tanaka, J. Inorg. Nucl. Chem. 1972, 34, 625.

11. J. K. Kochi and R. V. Bubramanian, Inorg. Chem. 1965, 4, 1527.

12. K. B. Yatsimirskii and T. V. Mal'Kova, Russ. J. Inorg. Chem. 1961, 6, 426.

13. T. V. Mal'Kova and K. B. Yatsimirskii, Russ. J. Inorg. Chem. 1963, 8, 169.

14. Z. Z. Hugus and A. A. El Awady, J. Phys. Chem. 1971, 75, 2594. 